\title{
Determinant Factors of Non-Performing Loan among Non-Bank Financial Intermediaries in Malaysia
}

\author{
M. A. Zariyawati ${ }^{1}$, M. T. Hirnissa ${ }^{2} \&$ K. A. Muhammad-Mujb ${ }^{1}$ \\ ${ }^{1}$ School of Business and Economics, University Putra Malaysia, Malaysia \\ ${ }^{2}$ Faculty of Business, Accountancy and Social Science, Kolej University Poly-Tech MARA, Kuala Lumpur, \\ Malaysia \\ Correspondence: M. A. Zariyawati, School of Business and Economics, University Putra Malaysia, Malaysia. \\ E-mail: zariyawati@upm.edu.my
}

Received: February 6, 2021

Accepted: May 6, 2021

Online Published: June 26, 2021

doi:10.5539/ijbm.v16n8p48

URL: https://doi.org/10.5539/ijbm.v16n8p48

\begin{abstract}
This study aimed to investigate the determinants of non-performing loans (NPLs) using a case of the Non-Bank Financial Intermediaries (NBFIs) in Malaysia during the period from 2009 to 2018. The study revealed that the level of NPLs can be attributed to both NBFI-specific factors (internal factors) and macroeconomic factors. The assessments on panel data analysis were done using STATA software. The results show that NBFI size, Profit (ROA), Lending Interest Rate (IR), and Inflation (INF) have a significant positive relationship with NPLs. The findings reveal that NPLs tend to increase with the deteriorating bank's efficiency. The larger the NBFI size, higher profit, and high interest contribute to the increment of NPLs. Meanwhile, NPL also increases due to the change in economic condition, particularly with a rise in inflation rate. Hence, for NBFIs to decrease their NPLs, they should consider these factors during the lending process.
\end{abstract}

Keywords: non-performing loan, internal factor, macroeconomic factor, non-bank financial intermediaries

\section{Introduction}

The development of a financial system in Malaysia depends on the financial market and financial institutions. Financial institutions consist of banking institutions and non-bank financial intermediaries. Similar to banking institutions, NBFIs are also important within the financial system in Malaysia. The nature and scale of their activities are less complex and account for a much smaller share of the total credit intermediated by the banking system compared with that observed in some advanced economies during the global financial crisis (Pozsar et al., 2010). The role of NBFI is essentially to offer financial aid to the specific underserved market segment. In Malaysia, NBFI has a complementary role to banks in providing financial aid to specific market segments. For example, NBFIs function as fund providers when they grant the loan to small and medium and enterprises (SMEs). Specifically, the services provided by SME bank and Agro bank are more focused on the financing of the small business sector and agriculture-related activities, respectively. Due to SMEs' limited access to external financing such as from banks (Atanasova, 2012), the financing schemes by NFBIs offer vital assistance for SMEs to get funding or capital for business. This is essential, because SMEs, which comprise about $98 \%$ of the business establishments in Malaysia, provide the backbone of the Malaysian economy. SMEs can use their funds from NBFIs to expand their business and increase profits, which further contribute to the Malaysian economy. Hence, the survival of NBFI is crucial.

However, NBFI cannot continue their function as fund resources to SMEs if the repayment rate from SMEs is low. This will increase the rate of the non-performing loan (NPLs) of NBFIs (Murthy et al., 2017). NPLs include advances and loans that remain unpaid. A loan is considered an NPL if it does not produce interest and a principal amount for a minimum of 90 days. Loans become NPLs if their principal amount and interest are not yet paid on the maturity date and are not anticipated for future dates. NPLs are used to measure credit risk that affects the financial institution and a sign of financial crisis in the economy. Hence, NBFIs with high NPLs are exposed to high risk. High credit risk will affect the performance of NBFIs due to the operating costs (Kingu, Macha \& Gwahula, 2018) and the liquidity problem. NBFIs have limited or no funds to further provide loans to new or other SMEs to generate income. Hence, the function of NBFIs is not achieved when NBFIs cannot survive. Continuously, this situation affects SMEs' contributions and therefore affects Malaysian economics. 
Hence, NBFI should know the factors that influence NPLs to mitigate the problem. This will ensure the survival of NBFIs.

NBFI borrowers can encounter problems making monthly repayments as a result of no income or less profit, especially during an economic turndown. Economic conditions and other macroeconomic factors (such as GDP growth, unemployment, and interest rate), bank-specific factors (return on equity, return on assets, capital adequacy ratio, and loan to deposit ratio), and institutional factors (bank size) can affect NPLs (Wood and Skinner, 2018). In addition, Ismail et al. (2017) examine the impacts of the financial institution towards the NPLs of firms in Malaysia during the period of 2008 to 2015 using the regression analysis method. Their finding shows that the size of financial institutions significantly negatively relates to NPLs. Hence, the purpose of this study is to investigate the determinant factors of NPLs among NBFIs in Malaysia. Most of the research about the determinants of NPLs only focuses on banking institutions though NBFI and their important role in the development of the financial system in Malaysia. Perhaps this study could serve as a guideline to NBFI in mitigating the issue of NPLs.

\section{Literature Review}

NPLs are unprofitable facilities or loans (Amuakwa-Mensah \& Boakye-Adjei, 2015). Whereas, Fofack (2005) used NPLs and bad loans interchangeably. Berger and De Young (1997) described NPLs as problem loans. In the broader context, NPLs can be considered as outstanding loans in interest as well as in principal for a period of time contrary to the terms and conditions set out in the loan agreement. The extant literature on NPLs suggests that determinants can be categorized into internal and external factors. Internal factors, size of firm, profit, capital adequacy ratio, total loan amount, and interest rate are important determinants of NPLs (Mohanty, Das \& Kumar, 2018). Meanwhile, economic growth (GDP) and inflation are categorized as the external factors of NPLs (Mohanty et al., 2018).

A substantial number of empirical findings support the internal factors of NPLs. Ranjan and Dhal (2003) studied the impact of firm size on NPLs in the Indian banking system. Their study found that terms of credit have a significant impact on NPLs in the Indian banking system due to the size of the banks and the presence of macro-economic shocks. Moreover, the size of the banks has a negative impact on NPLs if measured in terms of assets. If measured in terms of capital, however, it has a significant positive effect on the NPLs. Additionally, Amuakwa-Mensah and Boakye-Adjei (2015) also found that large banks have a greater effect on NPLs compared to small banks due to the fact that large banks have a larger and wider customer base than small banks.

Park and Zhang (2012) examined the determinant factors of NPLs in the United States. They considered solvency ratio, ROE, NIM Ratio, inefficiency ratio, and bank size as bank-specific determinants of NPL. The ROE and NIM ratio, which represent profit or performance of the financial institution, have a positive and significant impact on NPLs in the United States. However, Beaton, Myrvoda, and Shernnel Thompson (2016) assessed the factors of NPLs in the Eastern Caribbean Currency Union (ECCU) and found that more profitable banks tend to have lower NPL ratios. In the ECCU, higher bank profitability is associated with lower NPLs levels (as demonstrated by the return on assets of banks), which can reflect the quality of bank management. Both studies proved that the profits of the bank or financial intuitions influence NPLs.

The capital adequacy ratio evaluates the risk that a bank can undertake. The capital adequacy ratio is determined by applying Tier 1 capital to Tier 2 capital and dividing it by risk-weighted assets under the Basel accord. Generally, capital adequacy ratios widely used in similar studies are not clear regarding whether they positively or negatively affect the aggregate NPLs (Rahman, Asaduzzaman \& Hossin, 2017). Based on the study done by Rahman et al. (2017), the capital adequacy ratio has a negative impact on gross non-performing loans. This finding supports the studies of Sinkey and Greenawlat (1991), Mukherjee (2003). According to Mukherjee (2003), the existence of a large amount of NPLs is responsible for the decline in the profit margin of financial institution. In contrast, Reddy (2015) suggested that capital adequacy ratio is negatively associated with NPLs, while operating cost ratio is positively related.

Studies also revealed a significant impact between financial institutions' total loan and NPLs. Tomak (2013) studied the determinants of bank lending behavior on a sample of Turkish banks and demonstrated a significant relationship between NPL and bank lending behavior in state-owned banks. NPLs have a negative impact on the growth of total loans. The higher rate of NPLs could reduce the growth of total loan disbursement to the borrower. Furthermore, the lending rate can be used as a proxy for interest rates charged against loans and advances (Rajha, 2016). Higher interest rates weaken borrowers' ability to repay and further raise their debt burden further. Thus, interest rates and NPLs could have a positive association. Higher interest rate charges to the borrower can result in high NPL due to the inability of borrowers to make payments. Extensive empirical 
evidence shows a positive relationship between interest rate and NPLs (Beck, Jakubik and Piloiu, 2015; Patra and Padhi, 2016). Additionally, Beck et al. (2015) found that the growth rate of real GDP, movement of share prices, exchange rate, and lending interest rates play an important role in influencing the NPL ratio of 75 countries as demonstrated in their study. This reveals that macroeconomic factors affect the NPLs of financial institutions.

Many works of literature studied the impact of external factors, such as economic growth (GDP), inflation, and unemployment on NPLs. According to Mohanty, Das, and Kumar (2018), higher GDP growth commonly leads to further income and raises borrowers' debt servicing capability. Therefore, they lead to NPL reduction and vice versa. There are a large number of empirical findings that have approved the inverse relationship between economic growth and NPLs (Reddy, 2015; Rajha, 2016; Prasanna et al., 2014; Mohanty et al., 2018). For instance, Prasanna et al. (2014) explored the determinants of the NPLs for 31 Indian banks during the period 2000 to 2012. The study examined factors of economic growth, stock market index, per capita income growth, foreign exchange reserves, construction expenditures, bank size, performances, repo interest rate, exchange rate, and inefficiency ratio. Their findings highlight that economic growth has an inverse relationship with NPLs in the Indian banking system. This is because, when the economy is growing, firms request more loans. Firms use the funds as capital to produce more income, and thus they can repay the loans more easily, which results in lower NPLs. However, when the economy comes to a standstill, firms experience greater distress and difficulty repaying debts. Consequently, such distress increases the NPL level, and thus it can be concluded that GDP has a greater impact on NPLs.

Rajha (2016) found that inflation has a negative impact on NPLs, whereas global financial crisis has a positive impact on NPLs in Jordanian Banks over the period 2007 to 2012. This is in parallel to a later study done by Kjosevski and Petkovski (2017) that examined unbalanced panel data of 27 banks of the Baltic States and found that inflation growth is positively related to NPL. This is because high inflation slows down the growth rate and detracts NPL (Zheng, Perhiar, Gilal, \& Gilal, 2019). Zheng et al. (2019) also argued that the negative relationship between inflation and NPL in some models of financial institution is not impacted by fluctuations of inflation and political involvement in management. In particular, government-owned financial institutions enforce regulations on lending interest rates to control inflation.

\section{Method}

A quantitative approach is used in this study, and secondary data is sourced from the financial report of NBFI in Malaysia. The sample of this study will cover all local NBFIs (Agrobank, SME bank, AIM, MARA etc) in Malaysia. Annual data covers ten years ranging from the period of 2009 to 2018 in order to provide current inferences. The data were analyzed using Stata version 13.0 software. The static panel data analysis is used in this paper as it controls the necessary mechanism to deal with both inter-temporal dynamic behaviour and the individualistic of the firms. It allows controlling on heterogeneity bias due to the confounding effect of time-invariant variables omitted or hidden factors from the regression model. Furthermore, this longitudinal approach provides additional information and a richer source of variation through the utilization of a large number of data points. This will increase the degrees of freedom and reducing the co-linearity among explanatory variables, thus improving the efficiency of econometric estimators.

Moreover, certain unobservable effects may be presented in the data when time-series and cross-section data are combined in the estimation of a regression equation. Both unobservable firm-specific and time-specific factors are expected to have an impact on non-performing loan. Generally, there is three-technique use to test static panel data, 1) Pooled Ordinary Least Square (OLS), 2) Random effect model, and 2) Fixed effect model. OLS is preferred when there are no unique attributes of individuals within the measurement set and no universal effects across time. When there are unique attributes of individuals, random effect and fixed effect are preferred. The random effect technique assumes variation of entitled variable (variables) to be random and uncorrelated within the predictor or independent variable. In random effect, an individual characteristic that may or may not influence the predictor needs to be specified. Fixed effect model assumes substance within a variable, capable of producing effect or bias of the predictor or outcome of the variable. Fixed effect technique also expects that tested model is time-invariant model, characteristic is unique to specified variable and should not be related to other variable characteristics. To determine the best model between random and fixed techniques, the Hausman test can be applied to point the appropriate result of the study.

The independent variables for this study include NBFI size (SIZE), NBFI profit (ROA), total loan (TL), interest rate (IR), gross domestic product (GDP), and inflation (INF). Measurement of the variables are exhibited in Table 1. Meanwhile, the dependent variable is impairment loans, which represent non-performing loans (NPLs) 
of NBFIs. The relationship between NPLs and its factors determinant can be expressed in the model as follows:

$$
N P L i, t=\alpha+\beta 1(\text { SIZE) } i, t+\beta 2(R O A) i, t+\beta 3(\text { IR) } i, t+\beta 4(T L) i, t+\beta 5(G D P) i, t+\beta 6(I N F) i, t+\varepsilon i, t
$$

where:

Yit is the dependent variable (NPL) pooling $\mathrm{N}$ cross sectional observations and t time series observations;

i. $\quad \alpha$ is the intercept or constant;

ii. Vector Xit contains K explanatory variable (internal \& macroeconomic) for NBFI i in year t;

iii. Vector $\beta$ contains $\mathrm{K}$ regression coefficients or parameters to be estimated;

iv. $\quad$ it is the error term or disturbance term and by assumptions $\mathrm{E}($ cit $)=0$ and $\operatorname{Var}(\varepsilon i \mathrm{t})=\sigma \varepsilon 2$

Table 1. Variables definitions

\begin{tabular}{|c|c|c|}
\hline No. & Variable & Interpretation \\
\hline 1. & NPL & $\begin{array}{l}\text { Substandard loan, doubtful loan, loss, or provision to non-performing loan on the firm's } \\
\text { balance sheet }\end{array}$ \\
\hline 2. & SIZE & NBFI's total asset \\
\hline 3. & ROA & Return on asset $=$ Net Income $/$ Total Assets \\
\hline 4. & $\mathrm{TL}$ & Total Loan/Total Deposit \\
\hline 5. & IR & Base rate is the minimum rate set by the BNM (central bank of Malaysia) \\
\hline 6. & GDP & Gross Domestic Product value * NBFI Gross loan \\
\hline 7. & INF & Consumer Price Index * NBFI Gross loan \\
\hline
\end{tabular}

Table 2 shows the descriptive statistics of dependent and independent variable use in the current study. The mean of NPLs of all NBFIs over the ten years is 11.0548. NBFI could not recover 11.0548 for each loan provided to the borrowers. The highest NPL is 13.8152 , while the lowest is 8.8479 . NBFI size mean is 16.9058 , with the highest at 18.8714, while the smallest is at 16.4266 . The mean value of interest rate (IR) is 11.7617 , with a standard deviation of 1.3578 , meaning that interest rate can vary from the mean value to both sides by 1.3578 percent. The mean for the entire loan is 1.5462, with the highest at 2.6209. Among the macro-economic variables, the mean GDP rate is 12.4242 percent, while the mean for inflation (INF) is 11.9653 .

Table 2. Descriptive statistics

\begin{tabular}{lllll}
\hline Variable & Mean & Std. Deviation & Min & Max \\
\hline NPL & 11.0548 & 1.3163 & 8.8479 & 13.8152 \\
SIZE & 16.9058 & 0.8691 & 15.4266 & 18.8714 \\
ROA & 0.0136 & 0.0313 & 0.0051 & 0.0204 \\
IR & 11.7617 & 1.3578 & 8.1767 & 0.8921 \\
TL & 1.5462 & 0.3645 & 10.74851 & 1.3849 \\
GDP & 12.4242 & 0.9748 & 10.0901 & 15.0744 \\
INF & 11.9653 & 0.9591 & 12.7962 \\
\hline
\end{tabular}

Table 3 shows the correlation matrix of the dependent variable and independent variables in this study. Correlation analysis is used to explain the relationship between NPL and other variables. The table shows that NBFI size, ROA, IR, TL, and both macroeconomic factors have a positive relationship with the NPL. No problem of multicollinearity between dependent and independent variables was found, because the values of all the variables were less than 0.80 . 
Table 3. Correlation statistics

\begin{tabular}{|c|c|c|c|c|c|c|c|}
\hline & NPL & SIZE & ROA & IR & TL & GDP & INF \\
\hline NPL & 1.0000 & & & & & & \\
\hline SIZE & 0.6454 & 1.0000 & & & & & \\
\hline ROA & 0.5119 & 0.4070 & 1.0000 & & & & \\
\hline IR & 0.7035 & 0.4481 & 0.2355 & 1.0000 & & & \\
\hline TL & 0.5714 & 0.6047 & 0.4230 & 0.5039 & 1.0000 & & \\
\hline GDP & 0.6513 & 0.5668 & 0.4592 & 0.5840 & 0.4414 & 1.0000 & \\
\hline INF & 0.5133 & 0.4179 & 0.2965 & 0.4811 & 0.5139 & 0.4303 & 1.0000 \\
\hline
\end{tabular}

Table 4 presents the Pooled OLS, Random Effects, and Fixed Effects estimations of the determinants of non-performing loan with all the independent variables in this study. According to the Pooled OLS estimation, five out of six independent variables have a significant relationship with the non-performing loan. Only the factor of total loan is not significant. Next, the appropriation of Pooled OLS estimation for the determinants of NPL was investigated. The p-value for the Breusch-Pagan Lagrangian Multiplier (LM) test shown in Table 4 is 0.000 , which shows significance at $5 \%$. This p-value rejected the null hypothesis that the slopes and intercepts are the identical across NBFIs. Hence, random effects are better estimations for determinants of NPL in NBFI rather than Pooled OLS estimation.

The results of the random effect estimation in Table 4 are similar to the Pooled OLS estimation results. All independent variables have significant relationships, except for total loan. Meanwhile, Table 4 also reveals that two factors (total loan and GDP) have no significant relationship in the Fixed Effect estimation. Furthermore, the Hausman test was carried out to compare the appropriateness of fixed effect with random effect estimation to select the most appropriate estimation. The p-value of the Hausman test is 0.000 , which is smaller than 0.05 . This reveals that the fixed-effect model is the best model compared to the random effects model. Therefore, we discuss the result of fixed effect, since it is the most appropriate model to explain the findings on factors of NPL in NBFI.

Table 4. Regression analysis

\begin{tabular}{llll}
\hline $\begin{array}{l}\text { Dependent variable: NPL } \\
\text { Independent } \\
\text { Variables }\end{array}$ & Pooled OLS & Random Effects & Fixed Effects \\
\hline SIZE & 0.3687 & 0.3473 & 0.2517 \\
& $(0.000)^{* * *}$ & $(0.000)^{* * *}$ & $(0.021)^{* *}$ \\
ROA & 0.6875 & 0.6712 & 0.9432 \\
& $(0.000)^{* * *}$ & $(0.000) * * *$ & $(0.000) * * *$ \\
IR & 0.3876 & 0.4502 & 0.5154 \\
& $(0.000)^{* * *}$ & $(0.000)^{* * *}$ & $(0.000)^{* * *}$ \\
TL & 0.0632 & -0.1306 & -0.2499 \\
& $(0.731)$ & $(0.504)$ & $(0.255)$ \\
GDP & 0.1454 & 0.1380 & 0.1188 \\
& $(0.031)^{* *}$ & $(0.059) *$ & $(0.163)$ \\
INF & 0.1016 & 0.1123 & 0.1260 \\
& $(0.089) *$ & $(0.050)^{*}$ & $(0.036) * *$ \\
Constant & 9.9786 & 9.7777 & 9.5723 \\
& $(0.001)$ & $(0.009)$ & $(0.265)$ \\
LM Test & 0.000 & & \\
Hausman Test & & 0.000 & \\
Notes. ***Significant at 1 percent, **Significant at 5 percent, *Significant at 10 percent. Parentheses are p-values.
\end{tabular}

Notes. $* * *$ Significant at 1 percent, $* *$ Significant at 5 percent, $*$ Significant at 10 percent. Parentheses are p-values.

\section{Discussion}

The results of this study revealed that NBFI size, Profit (ROA), Interest Rate (IR), and Inflation (INF) have a positively significant relationship with NPLs of NBFIs. This suggests that, when NBFI size, Profit (ROA), Interest Rate (IR), and Inflation (INF) increase, they will lead to the increment of non-performing loans in NBFIs. 
NBFI size positively affects NPLs of NBFIs at a significant level of 5\%, which suggests that large NBFIs have a high amount of NPLs compared to small NBFIs. However, this is inconsistent with the prior study done by Ismail et al. (2017). We found that larger NBFIs have more funds for granted loan than small NBFIs. More loans are granted, but not all are quality loans due to the possibility of having a greater amount of unpaid loans by the borrower. Hence, more loans granted could result in more NPLs, particularly when the NBFIs have a weak credit policy.

Furthermore, the results also revealed that NBFI profitability also positively and significantly affect NPLs at the $1 \%$ level. The higher the profit of the NBFI, the higher the NPLs, which support the work done by Park and Zhang (2012). NBFIs, which have higher profit, can easily lend money to the borrower without making critical analysis on the borrower's capability to perform repayment. The error in granting loans to the incapable borrower will result in the increments of NPLs.

The interest rate of NBFIs is also positive and significant at the $1 \%$ level. This is in parallel to the study done by Beck, Jakubik, and Piloiu (2015) and Patra and Padhi (2016). When NBFIs extend high interest rate charges to customers, it contributes to high NPLs. High interest rates affect the borrower, of whom most from SMEs are less capable of paying loans. The cost of financing is higher compared to the SMEs or borrower incomes. Hence, it is difficult for them to make repayment. Consequently, this will increase the level of NPLs in NBFI.

Inflation represents a country's economic condition. This factor is positively significant at the $5 \%$ level with NPLs. It indicates that the changes in inflation will affect the NPLs of NBFIs. The higher the inflation rate, the greater the level of NPLs will increase. This finding is in contrast to the outcome study done by Mondal (2016). However, this makes sense, since the results of the current study are consistent with the findings on the relationship between interest rate and NPL. During inflation, interest rates increase, as does the cost of borrowings. Hence, borrowers that have cashflow or income problems may face difficulty making repayment due to the high cost.

\section{Conclusion}

The main aim of this study was to identify the determinant factors of NBFI NPLs in Malaysia. NBFIs in Malaysia should consider both internal and macroeconomic factors in order to lessen the rate of non-performing loans (NPLs). Therefore, this study recommends that, to solve the challenge of NPLs, NBFI management focus on their size, profitability, lending interest rate, and economic situation, which are represented by inflation level, when planning for lending activities. By doing this, NBFI managers can then manage their problem loans effectively and efficiently. As a result, this might lead to the increment of profitability of NBFI while providing value to the shareholders.

\section{Acknowledgements}

This project was supported by URG KUPTM grant, award number URG/1219/FBASS/FP02779(01). The authors would like to thank the Research Assistants, Nadiatul Natasha binti Mohd Fawzi, in for helping us to complete this research.

\section{References}

Amuakwa-Mensah, F., \& Boakye-Adjei, A. (2015). Determinants of non-performing loans in Ghana banking industry. International Journal of Computational Economics and Econometrics (IJCEE), 5(1).

Atanasova, C. (2012). How do firms choose between intermediary and supplier finance? Financial Management, 41(1), 207-228.

Beaton, K., Myrvoda, A., \& Thompson, S. (2016). Non-Performing Loans in the ECCU: Determinants and Macroeconomic Impact. IMF Working Paper No. 16/229.

Beck, R., Jakubik, P., \& Piloiu, A. (2015). Key Determinants of Non-performing Loans: New Evidence from a Global Sample. Open Econ Rev, 26, 525-550. https://doi.org/10.1007/s11079-015-9358-8

Berger, A. N., \& DeYoung, R. (1997). Problem Loans and Cost Efficiency in Commercial Banks. Journal of Banking \& Finance, 21(6). 849-870. https://doi.org/10.1016/S0378-4266(97)00003-4

Fofack, H. (2005). Non-Performing Loans in Sub-Saharan Africa: Causal Analysis and Macroeconomic Implications. World Bank Policy Research Working Paper No. WP3769. https://doi.org/10.1596/1813-9450-3769

Ismail, N., Azlan, N. D. A., Husin, M. M., Ishak, I., \& Hashim, S. L. M. (2017). Bank Efficiencies and Non-Performing Loan of Commercial Banks in Malaysia. Journal of Humanities, Language, Culture and 
Business (HLCB), 1(5), 34-40. http://dx.doi.org/10.6007/IJARBSS/v8-i10/4773

Kingu, P. S., Macha, S., \& Gwahula, R. (2018). Impact of non-performing loans on bank's profitability: Empirical evidence from commercial banks in Tanzania. International Journal of Scientific Research and Management, 6(1). https://doi.org/10.18535/ijsrm/v6i1.em11

Kjosevski, J., \& Petkovski, M. (2017). Non-Performing Loans in Baltic States: Determinants and Macroeconomic Effects. Baltic Journal of Economics. 17(1). 25-44. https://doi.org/10.1080/1406099X.2016.1246234

Mohanty, A. R., Das, B. R., \& Kumar, S. (2018). Determinants of Non-Performing Loans in India: A System GMM Panel Approach. Prajnan.

Mondal, T. (2016). Sensitivity of Non-Performing Loan to Macroeconomic Variables: Empirical Evidence from Banking Industry of Bangladesh. Global Journal of Management and Business Research.

Mukherjee, P. (2003). Dealing with NPAs: Lessons from International Experience. Money \& Finance ICRA Bulletin, 64-90.

Murthy, U., \& Mariadas, P. A. (2017). An Exploratory Study on the Factors Contributing Loan Repayment Default among the Loan Borrowers in Micro Finance Institutions in Shah Alam, Selangor. International Journal of Business and Management, 12(12), 242-250. https://doi.org/10.5539/ijbm.v12n12p242

Park, J. H., \& Zhang, L. (2012). Macroeconomic and Bank-Specific Determinants of the U.S. NonPerforming Loans: Before and During the Recent Crisis. Journal of Financial Services Research, 4-8.

Patra, B., \& Padhi, P. (2016). Determinants of Nonperforming Assets-Bank-Specific and Macroeconomic Factors: A Panel Data Analysis of Different Group of Commercial Banks Operating in India. Theoretical and Applied Economics, 23(4), 215-236.

Pozsar, Z., Adrian, T., Ashcraft, A., \& Boesky, H. (2010). Shadow Banking. New York, 458(458), 3-9.

Prasanna, P. K., Thenmozhi, M., \& Rana, N. (2014). Determinants of Non-Performing Advances in Indian Banking System. Banks and Bank Systems, 9(2). 65- 77.

Rajha, K. S. (2016). Determinants of Non-Performing Loans: Evidence from the Jordanian Banking Sector. Journal of Finance and Bank Management, 4(1), 125-136. https://doi.org/10.15640/jfbm.v4n1a9

Rahman, M. A., Asaduzzaman, M., \& Hossin, M. S. (2017). Impact of Financial Ratios on Non-Performing Loans of Publicly Traded Commercial Banks in Bangladesh. International Journal of Financial Research, 8(1), 181-188. https://doi.org/10.5430/ijfr.v8n1p181

Rajan, R., \& Dhal, S. C. (2003). Non-performing loans and terms of credit of public sector banks in India: An empirical assessment. Reserve Bank of India Occasional Papers, 24(3), 81-121.

Reddy, K. S. (2015). Non-Performing Loans in Emerging Economies - Case Study of India. Asia. Journal of Finance \& Accounting, 7(1). 183-206. https://doi.org/10.5296/ajfa.v7i1.7687

Tomak, S. (2013). Determinants of Commercial Bank’ Lending Behavior: Evidence from Turkey. Asian Journal of Empirical Research, 3(8), 933-943.

Wood, A., \& Skinner, N. (2018). Determinants of non-performing loans: evidence from commercial banks in Barbados. The Business \& Management Review, 9(3), 44-64.

Zheng, C., Perhiar, S. M., Gilal, N. G., \& Gilal, F. G. (2019). Loan Loss Provision and Risk-Taking Behavior of Commercial Banks in Pakistan: A Dynamic GMM Approach. Sustainability Journal. https://doi.org/10.3390/su11195209

\section{Copyrights}

Copyright for this article is retained by the author(s), with first publication rights granted to the journal.

This is an open-access article distributed under the terms and conditions of the Creative Commons Attribution license (http://creativecommons.org/licenses/by/4.0/). 